\title{
The host range, annual cycle and parasitoids of the African rice gall midge Orseolia oryzivora (Diptera: Cecidomyiidae) in central and southeast Nigeria
}

\author{
C.T. Williams ${ }^{1 *}$, O. Okhidievbie ${ }^{1}$, K.M. Harris ${ }^{1}$ and \\ M.N. Ukwungwu ${ }^{2}$
}

${ }^{1}$ West Africa Rice Development Association/CAB International African Rice Gall Midge Project, c/o CABI Bioscience, Silwood Park, Buckhurst Road, Ascot, Berks, SL5 7TA, UK: ${ }^{2}$ National Cereals Research Institute

(NCRI), Badeggi, PMB 8, Bida, Nigeria

\begin{abstract}
Host range experiments and field sampling in Nigeria produced no evidence that African rice gall midge, Orseolia oryzivora Harris \& Gagné, can develop on plants other than Oryza species. Sampling in three outbreak areas during 1994 showed that the insect's annual cycle varied according to the agroecological zone and rice cropping pattern. In the humid forest zone, Orseolia oryzivora persisted through the short dry season on ratoons of cultivated rice Oryza sativa at a rainfed site and on dry season rice crops at an irrigated one. In contrast, at rainfed sites in the moist savannah zone the pest survived the longer dry season on the perennial wild rice $O$. longistaminata, while ratoons and volunteers of $O$. sativa provided 'bridges' between the wild host and wet season rice crops. Early in the wet season at rainfed sites, galls of Orseolia oryzivora were not found at high density on wild rice, ratoons or volunteers. The heavy infestations which developed by October resulted primarily from rapid multiplication on rice crops themselves during the wet season. At all 13 sites sampled, the large majority of galls were found on fallow or cropped rice fields, rather than in ditches, bunds or uncultivated wetland, irrespective of the time of year or the hosts involved. From gall dissections, the parasitoids Aprostocetus procerae (Risbec) and Platygaster diplosisae Risbec caused over $30 \%$ mortality at some sites by October but generally increased too late to prevent crop damage. Implications of the results for the management of Orseolia oryzivora are discussed.
\end{abstract}

\section{Introduction}

The African rice gall midge, Orseolia oryzivora Harris and Gagné (Diptera: Cecidomyiidae) is an indigenous pest of rice in sub-Saharan Africa (Commonwealth Institute of Entomology, 1984). It was first identified as a distinct species by Harris \& Gagné (1982), having previously been confused with the Asian rice gall midge Orseolia oryzae (Wood-Mason),

*E-mail: CharlesWilliams5@compuserve.com which does not occur in Africa. Since the late 1970s outbreaks of O. oryzivora on wet season rice crops have increased in Burkina Faso (Bonzi, 1980; Dakouo et al., 1988), Nigeria (Ukwungwu et al., 1989; Ukwungwu \& Joshi, 1992) and several other African countries (e.g. Alam et al., 1985; Taylor et al., 1995). Those in Nigeria have damaged over 50,000 ha of rice, causing total yield loss on the worst affected fields (Ukwungwu et al., 1989). In rainfed lowland conditions even moderate infestation levels can cause substantial losses (Williams et al., 1999). 
Table 1. Locations, rainfall characteristics and agroecological zones of the Orseolia oryzivora outbreak areas studied, and the number of sites sampled in each area.

\begin{tabular}{|c|c|c|c|c|c|}
\hline $\begin{array}{l}\text { Location } \\
\text { (nearest large town) }\end{array}$ & $\begin{array}{l}\text { Latitude and } \\
\text { longitude of town }\end{array}$ & $\begin{array}{c}\text { Annual } \\
\text { rainfall }(\mathrm{mm})^{2}\end{array}$ & $\begin{array}{l}\text { Rainy } \\
\text { season }^{3}\end{array}$ & $\begin{array}{l}\text { Agroecological } \\
\text { zone }\end{array}$ & $\begin{array}{c}\text { Number } \\
\text { of sites sampled }\end{array}$ \\
\hline $\begin{array}{l}\text { Uyo, } \\
\text { Akwa-Ibom State }\end{array}$ & $\begin{array}{l}05^{\circ} 01^{\prime} \mathrm{N} \\
07^{\circ} 56^{\prime} \mathrm{E}\end{array}$ & 2444 & March to November & Humid forest & 3 \\
\hline $\begin{array}{l}\text { Abakaliki, } \\
\text { Ebonyi State }^{1}\end{array}$ & $\begin{array}{l}06^{\circ} 17^{\prime} \mathrm{N} \\
08^{\circ} 04^{\prime} \mathrm{E}\end{array}$ & 1833 & April to October & $\begin{array}{l}\text { Savannah/forest } \\
\text { transition }\end{array}$ & 6 \\
\hline $\begin{array}{l}\text { Bida, } \\
\text { Niger State }\end{array}$ & $\begin{array}{l}09^{\circ} 06^{\prime} \mathrm{N} \\
05^{\circ} 59^{\prime} \mathrm{E}\end{array}$ & 1183 & May to September & Moist savannah & 4 \\
\hline
\end{tabular}

${ }^{1}$ Until Ebonyi State was created in 1996 this outbreak area fell within Enugu State.

2 Average annual rainfall for 1985-1996. Data for the Uyo area were recorded at Onne, $90 \mathrm{~km}$ WSW of Uyo. Data sources: IITA Agroecological Studies Unit (Onne and Bida), Ikwo Agricultural College and Sudan United Mission, Ebonyi State (Abakaliki).

${ }^{3}$ Months for which average rainfall exceeds $100 \mathrm{~mm}$.

Orseolia oryzivora develops from egg to adult in three to five weeks and a female can lay 100-400 eggs within two to three days of emergence (Descamps, 1956; Anon., 1987; Bouchard et al., 1992; Umeh \& Joshi, 1993). Eggs are laid on the plant surface and the neonate larvae migrate between the leaf sheaths to attack the growing points of vegetative tillers. An infested tiller cannot initiate more leaves or a panicle and instead produces a hollow gall, within which the larva develops. When the insect reaches the pupal stage the gall elongates to form a tube, known as an 'onion leaf' gall, and within a few days the pupa matures, moves up the gall and cuts a hole near the tip, through which the adult midge emerges. The exposed eggs and neonate larvae require humid conditions, so outbreaks are associated with wet weather, and lowland (swamp) rice is more seriously affected than upland rice.

The literature contains conflicting information on the host range of $O$. oryzivora. Some authors give only wild and cultivated rice (Oryza spp.) as hosts (Descamps, 1956; Anon., 1987) but Bonzi (1980) and Brenière (1983) include other grasses. And although some data are available on the pest's population dynamics on cultivated rice during the wet season (Dakouo et al., 1988; Umeh \& Joshi, 1993) little is known of its ecology when rice crops are unavailable. Descamps (1956) provides the only detailed observations on the survival of Orseolia oryzivora from one rice-cropping season to the next, based on an early study in northern Cameroon.

Chemical control of O. oryzivora is difficult, costly and involves risks to human health, biological control agents and other non-target species, so improvements to cultural, biological and varietal control methods are urgently needed. These require more data on the pest's host plants, annual cycle, natural enemies and ecology off the crop. To provide some of this information, host range tests were carried out and year-round sampling was undertaken during 1994 in three major outbreak areas in Nigeria.

\section{Materials and methods}

\section{Host range experiments}

Simple 'no choice' tests of possible host plant species were carried out in mesh-covered $80 \times 80 \times 80 \mathrm{~cm}$ insect cages in a screenhouse at the International Institute of Tropical Agriculture (IITA), Ibadan, Nigeria. The literature on O. oryzivora and O. oryzae and the abundance of different grasses in the outbreak areas studied were used to decide which species to screen. Four species of Oryza and six other species of grasses (Poaceae) were tested (see table 3 ). The three annual species of Oryza were grown from seed obtained from the IITA Genetic Resources Unit. The remaining species were grown from seeds, seedlings or rhizomes collected from the field. Plant identifications were confirmed by the Weed Science Unit at IITA.

For each experiment, a cage containing potted plants of the test species at the seedling or early tillering stage was heavily infested with adult Orseolia oryzivora which had emerged within the previous $24 \mathrm{~h}$ in an insectary culture. The same number of midges from the same culture cages were also introduced into a 'control' cage containing pots of tillering ITA 306, a susceptible variety of Oryza sativa. For five to seven days after infestation, both cages were shaded and the plants sprayed with water at two-hourly intervals during the day to maximize survival of midge eggs and neonate larvae. Tillers and galls were counted on the test species and the control plants 30 to 35 days after infestation. All apparently healthy tillers were then dissected to check for small galls, usually after a further two to three weeks. The culture used was derived from galls collected from rice crops at IITA, Ibadan, and was maintained on ITA 306.

\section{Field sampling}

Three outbreak areas in different agroecological zones and with different seasonal rainfall patterns were selected for study (table 1). All have had regular outbreaks of Orseolia oryzivora since the late 1980s. Three to six sites were sampled in each area, the number varying according to site size and accessibility. The smallest sites were valleys less than $200 \mathrm{~m}$ across. The largest were floodplains over $1 \mathrm{~km}$ wide. Twelve of the 13 sites were rainfed, so farmers only grew lowland rice in the wet season, but one site near Uyo had year-round irrigation, so both wet season and dry season rice crops were grown. All the rice was transplanted except at two Bida sites, where some fields were direct-seeded. Around Bida and at one Uyo site both improved and traditional rice varieties were grown but at the others farmers only grew improved varieties. Most farmers applied mineral fertilizer but none used insecticide on their rice in 1994 (the year of the study). Planting of wet season rice was staggered over several months at all sites. In 1994 the first fields were planted in 
mid-June at most Uyo and Abakaliki sites and in late July at most Bida sites. The last were planted in August or September. The harvest was also staggered, starting in October and ending in December or January.

Sampling was carried out in five periods: 3 to 20 February, 21 April to 31 May, 7 to 24 July, 3 October to 2 November, and 1 to 17 December 1994. All three outbreak areas were sampled each time except for the Bida area, which was not visited in February. One Uyo site was not sampled in July because of deep flooding. A new site selected to replace it was visited in July and October. In each sampling period the main habitats at each site were sampled at predetermined intervals (usually 10 or 20 paces) along parallel transects. The sample unit used was either a rice hill (for rice crops) or a $25 \times 25 \mathrm{~cm}$ quadrat (for other habitats). Transect sampling patterns were adjusted to give approximately even coverage within each habitat. The area covered by the transects varied from about 2 ha at the smallest sites to about 50 ha at the largest, and the total units sampled per site per period varied from 100 to 950 . The variation was due to differences in site size and the time and manpower available.

When sampling rice crops, $30-50$ hills were examined in each sampled field to estimate the percentage of tillers with galls. At small sites all the fields were sampled but at large ones every third field was selected, giving a total of 10-20 for the site. When sampling habitats other than rice crops, all the Poaceae in each quadrat were searched for galls and identified to genus or species with the help of the Weed Science Unit, IITA, who checked pressed specimens. Numbers of galls in each quadrat and the host species they were on were recorded. At Uyo and Abakaliki in July and in all three areas in October, rice crops were far more abundant than any other possible hosts so other plants were not sampled at these times.

As well as quadrats sampled along transects, many additional ones containing species of Poaceae suspected to be hosts of $O$. oryzivora were searched in April/May, bringing the total to over 1000 for several species (table 5). Extra quadrats were also searched in December. The suspected hosts were genera mentioned in the literature as hosts of $O$. oryzivora or O. oryzae, and grasses which were particularly abundant.

Habitats at the sampled sites are listed in table 2 . Uncultivated wetland and rice nurseries were not transectsampled because they were restricted to small areas. But many additional quadrats containing suspected hosts were searched in uncultivated wetland and the nurseries were also inspected for galls. Upland areas were examined in February and April/May but were not sampled systematically because they had very little grass cover and species mentioned in the literature as hosts of O. oryzivora were much less abundant than in other habitats. The exceptions were a few fields of upland rice near one Abakaliki site, which were sown in May and transectsampled in July.

For each sampling period, the gall density (galls per $\mathrm{m}^{2}$ ) on each host species in each habitat was estimated, either directly from the transect data or, if galls were rare, indirectly by combining data from transect and additional quadrats. When rice crops were present, gall densities on them were calculated from the percentage of tillers with galls and the numbers of tillers per hill and hills per $\mathrm{m}^{2}$. An average gall density was calculated for each whole site based on the habitat estimates and the relative areas of each habitat. It was not possible to calculate within-site error terms for most of these gall densities because they were not direct estimates.

All galls found on hosts other than Oryza sativa were dissected to rear specimens of Orseolia and parasitoids for identification and determine parasitism levels. Orseolia specimens were identified by $\mathrm{KMH}$, and the parasitoids by $\mathrm{J}$. LaSalle and A. Polaszek of CABI Bioscience. When galls on Oryza sativa were rare they were all dissected but when abundant, random samples of 50-100 were taken per site. These samples included newly-elongated galls and older ones from which midges or parasitoids had already emerged. Older galls were included because ignoring them overestimates parasitism, as parasitoids remain in galls longer than unparasitized Orseolia oryzivora.

Table 2. Habitats at field sites where Orseolia oryzivora galls were sampled during 1994.

\begin{tabular}{ll}
\hline Habitat & Characteristics \\
\hline Lowland rice crops & $\begin{array}{l}\text { Absent from December/January to June/July at all } 12 \text { rainfed sites. Present all year } \\
\text { at the irrigated site near Uyo. }\end{array}$
\end{tabular}

Fallow fields (lowland rice fields left fallow between one wet season and the next)

Dryland cropped fields (lowland rice fields used to grow cassava or vegetables in the dry season)

Permanent bunds and ditches

Uncultivated wetland

Neighbouring upland

Rice nurseries
Present in dry season at all rainfed sites, forming $5 \%$ to $100 \%$ of rice field area (mean: 56\%). Rice stubble often burnt off or grazed in dry season.

Present in dry season at 11 rainfed sites, forming $5 \%$ to $95 \%$ of rice field area Dryland crops were normally grown on mounds made after the rice harvest and flattened before the next rice crop was planted.

Only present at four sites. At others, temporary bunds and ditches made for rice cropping were destroyed before dryland crops were planted in the dry season.

Restricted to small patches, such as edges of ponds.

Cultivated with dryland crops and normally left fallow in dry season. Included a few fields of upland rice near one Abakaliki site.

Covered a few $\mathrm{m}^{2}$ at some sites in May and July. At others, nurseries were close to farmers' houses and not near rice fields. 
Table 3. Results of 'no-choice' host range tests on Orseolia oryzivora.

\begin{tabular}{|c|c|c|c|c|c|}
\hline \multirow[b]{2}{*}{ Test plant species } & \multicolumn{2}{|c|}{$\begin{array}{l}\text { Percent of tillers with } \\
\text { galls on: }\end{array}$} & \multirow{2}{*}{$\begin{array}{l}\text { Total number of } \\
\text { tillers on test plants }\end{array}$} & \multicolumn{2}{|c|}{$\begin{array}{c}\text { Initial infestation } \\
\text { (adult Orseolia oryzivora } \\
\text { per cage) }\end{array}$} \\
\hline & Test plants & O. sativa controls & & female & male \\
\hline Oryza barthii & 8.0 & 43.9 & 473 & 21 & 18 \\
\hline O. longistaminata & 15.1 & 43.9 & 93 & 21 & 19 \\
\hline O. punctata & 32.6 & 56.3 & 141 & 29 & 4 \\
\hline O. stapfii & 29.9 & 56.3 & 268 & 29 & 4 \\
\hline Acroceras zizanioides & 0 & 53.9 & 224 & 64 & 15 \\
\hline Echinochloa colona & 0 & 74.5 & 303 & 37 & 19 \\
\hline E. stagnina & 0 & 77.8 & 209 & 50 & 8 \\
\hline Ischaemum rugosum & 0 & 77.4 & 105 & 47 & 13 \\
\hline Leersia hexandra & 0 & 43.6 & 257 & 54 & 9 \\
\hline L. hexandra ${ }^{1}$ & 0 & 56.6 & 294 & 67 & 5 \\
\hline Paspalum scrobiculatum & 0 & 87.9 & 195 & 50 & 22 \\
\hline P. scrobiculatum ${ }^{1}$ & 0 & 66.4 & 243 & 54 & 6 \\
\hline
\end{tabular}

${ }^{1}$ Tests on L. hexandra and P. scrobiculatum were repeated because, based on the literature, they were thought particularly likely to be hosts of O. oryzivora.

\section{Results}

\section{Host range experiments}

Orseolia oryzivora formed galls and completed its lifecycle on the four species of Oryza tested (table 3) though on all of these the percentage of tillers with galls was significantly lower than on O. sativa control plants tested in separate cages alongside (chi-squared tests: $\chi^{2}>15$, d.f. $=1, P$ $<0.001)$. No galls were formed on any of the other grasses which were screened, despite the fact that at least 100 tillers of each test species were present and the O. sativa control plants became heavily infested (table 3 ).

\section{Field results on host plants and habitats used}

In February, in the middle of the dry season, few grasses were growing and galls were only found at two sites, all on O. sativa. Most of the field data on host range were therefore obtained in April/May, by which time the first rains of the year had fallen at all the sites but rice crops had only been planted at two. The abundance of different grasses at this time varied with outbreak area and habitat (table 4). Volunteers of $O$. sativa (rice plants germinated from seed left on the soil at harvest) were quite common in all three areas but were still young seedlings. Ratoons (tillers sprouted from rice stubble) were very rare except at the Uyo sites

Table 4. Mean percent of transect quadrats containing Oryza species and other common grasses in the main habitats in three Orseolia oryzivora outbreak areas in April/May 1994.

\begin{tabular}{|c|c|c|c|c|c|c|c|c|}
\hline \multirow{2}{*}{$\begin{array}{l}\text { Locality } \\
\text { (and agroecological zone) } \\
\text { Main habitats }^{1}\end{array}$} & \multicolumn{3}{|c|}{$\begin{array}{c}\text { Bida } \\
\text { (moist savannah) }\end{array}$} & \multicolumn{2}{|c|}{$\begin{array}{l}\text { Abakaliki } \\
\text { (transition) }\end{array}$} & \multicolumn{3}{|c|}{$\begin{array}{c}\text { Uyo } \\
\text { (forest) }\end{array}$} \\
\hline & $\begin{array}{l}\text { Fallow } \\
\text { fields }\end{array}$ & $\begin{array}{l}\text { Dryland } \\
\text { cropped } \\
\text { fields }\end{array}$ & $\begin{array}{l}\text { Bunds } \\
\text { and } \\
\text { ditches }^{2}\end{array}$ & $\begin{array}{l}\text { Fallow } \\
\text { fields }\end{array}$ & $\begin{array}{l}\text { Dryland } \\
\text { cropped } \\
\text { fields }\end{array}$ & $\begin{array}{l}\text { Fallow } \\
\text { fields }\end{array}$ & $\begin{array}{l}\text { Dryland } \\
\text { cropped } \\
\text { fields }\end{array}$ & $\begin{array}{l}\text { Bunds } \\
\text { and } \\
\text { ditches }^{2}\end{array}$ \\
\hline \multicolumn{9}{|l|}{ Oryza species } \\
\hline O. sativa volunteers & 29 & 8 & & 11 & 6 & 1 & 13 & \\
\hline O. sativa ratoons & 1 & & & & & 4 & 1 & \\
\hline O. longistaminata & 17 & 12 & 17 & 5 & 6 & & & \\
\hline \multicolumn{9}{|l|}{ Other common grasses ${ }^{3}$} \\
\hline Acroceras zizanioides & & & & & & 33 & 26 & 15 \\
\hline Echinochloa colona & & & & 16 & 18 & & & \\
\hline Ischaemum rugosum & & & & 38 & 23 & & & \\
\hline Leersia hexandra & 42 & 37 & 68 & 46 & 17 & 15 & & 1 \\
\hline Panicum laxum & & & & 11 & & 60 & 86 & 8 \\
\hline Paspalum scrobiculatum & 9 & 17 & 20 & 23 & 44 & 4 & 29 & 3 \\
\hline Sacciolepis sp. & 1 & 13 & 11 & 3 & 1 & 3 & 2 & \\
\hline Total transect quadrats examined & 445 & 290 & 115 & 344 & 300 & 400 & 220 & 316 \\
\hline
\end{tabular}

${ }^{1}$ Dry season rice crops, which were present at two sites, are not included.

${ }^{2}$ Permanent bunds and ditches were absent from two of the four sites near Bida, and all those near Abakaliki.

${ }^{3}$ Less common grasses included: Axonopus compressus, A. flexuosus, Digitaria acuminatissima, D. horizontalis, Echinochloa pyramidalis, Eleusine indica, Eragrostis atrovirens, Imperata cylindrica, Leptochloa caerulescens, Panicum brevifolium, P. maximum, P. repens, Paspalum conjugatum, Pennisetum spp. and Sporobolus pyramidalis. 
Table 5. Total numbers of quadrats searched containing Oryza species and other common grasses in three Orseolia oryzivora outbreak areas in April/May 1994 and the Orseolia galls found in them.

\begin{tabular}{|c|c|c|c|c|c|c|}
\hline \multirow[t]{2}{*}{$\begin{array}{l}\text { Locality } \\
\text { (and agroecological zone) }\end{array}$} & \multicolumn{2}{|c|}{$\begin{array}{c}\text { Bida } \\
\text { (moist savannah) }\end{array}$} & \multicolumn{2}{|c|}{$\begin{array}{l}\text { Abakaliki } \\
\text { (transition) }\end{array}$} & \multicolumn{2}{|c|}{$\begin{array}{c}\text { Uyo } \\
\text { (forest) }\end{array}$} \\
\hline & $\begin{array}{l}\text { quadrats } \\
\text { searched }\end{array}$ & $\begin{array}{l}\text { galls } \\
\text { found }\end{array}$ & $\begin{array}{l}\text { quadrats } \\
\text { searched }\end{array}$ & $\begin{array}{l}\text { galls } \\
\text { found }\end{array}$ & $\begin{array}{l}\text { quadrats } \\
\text { searched }\end{array}$ & $\begin{array}{l}\text { galls } \\
\text { found }\end{array}$ \\
\hline \multicolumn{7}{|l|}{ Oryza species } \\
\hline O. sativa volunteers & 780 & & 703 & & 174 & \\
\hline O. sativa ratoons & 6 & & 0 & & 288 & 2 \\
\hline O. longistaminata & 2407 & 23 & 1127 & & 10 & \\
\hline \multicolumn{7}{|l|}{ Other common grasses } \\
\hline Acroceras zizanioides & 0 & & 0 & & 332 & \\
\hline Echinochloa colona & 0 & & 465 & & 0 & \\
\hline Ischaemum rugosum & 2 & & 620 & & 0 & \\
\hline Leersia hexandra & 552 & & 494 & & 231 & \\
\hline Panicum laxum & 0 & & 54 & & 447 & \\
\hline Paspalum scrobiculatum & 545 & $15^{1}$ & 883 & $155^{1}$ & 486 & $53^{1}$ \\
\hline Sacciolepis sp. & 59 & & 25 & & 16 & \\
\hline
\end{tabular}

${ }_{1}^{1}$ Galls on Paspalum were not produced by O. oryzivora (see text and Harris et al., 1999).

Quadrats searched include those along transects (used to obtain the plant abundance estimates in table 4) and additional quadrats containing suspected O. oryzivora host plants. For galls found, zero values are not shown.

because north of the forest zone nearly all the previous year's stubbles had died during the long dry season. The perennial wild rice Oryza longistaminata A. Chev. \& Roehr. was abundant at Bida, patchily distributed at Abakaliki and much rarer at Uyo. A few plants of Oryza barthii A. Chev. and Oryza glaberrima Steud. were also found. Several grasses of other genera were as or more widespread than O. longistaminata or O. sativa (table 4).

Over 10,000 quadrats containing Poaceae were searched in April/May but galls were found on only three species: O. sativa, O. longistaminata and Paspalum scrobiculatum L. (table 5). Pupae and adult midges collected from the galls on both Oryza species were Orseolia oryzivora but those from galls on P. scrobiculatum, which were much more common, were a morphologically distinct species of Orseolia (Harris et al., 1999). In December, 1350 quadrats containing grasses other than Oryza species were searched but again no galls of Orseolia oryzivora were found on them.
During February and April/May, all the O. oryzivora galls found were on fallow or dryland cropped fields or, at the irrigated site, on rice crops. Later in the year, a few were found in other habitats such as bunds, ditches and uncultivated wetland but these were never more than $5 \%$ of the total at a site, irrespective of the host plants involved.

\section{The annual cycle in each outbreak area}

Bida, in the moist savannah zone, had a longer dry season than the other two areas studied. In May, at the beginning of the wet season, O. oryzivora galls were found at low density at three of the four Bida sites, all on Oryza longistaminata (table 6, fig. 1). Most of these were attached to the leafless nodes of rhizomes buried up to $20 \mathrm{~cm}$ in mud, strongly suggesting that the larvae which produced them had infested the plants the previous year, before the aerial parts died back in the dry season. In early July, wet season

Table 6. Average abundance of Oryza species in April/May 1994 at each of 12 sites in three Orseolia oryzivora outbreak areas, and (in brackets) number of $O$. oryzivora galls per $\mathrm{m}^{2}$.

\begin{tabular}{|c|c|c|c|c|c|c|c|c|c|c|c|c|}
\hline \multirow{2}{*}{$\begin{array}{l}\text { Outbreak area } \\
\text { Agroecological zone } \\
\text { Site }^{1}\end{array}$} & \multicolumn{4}{|c|}{$\begin{array}{c}\text { Bida } \\
\text { moist savannah }\end{array}$} & \multicolumn{6}{|c|}{$\begin{array}{l}\text { Abakaliki } \\
\text { transition }\end{array}$} & \multicolumn{2}{|c|}{$\begin{array}{l}\text { Uyo } \\
\text { forest }\end{array}$} \\
\hline & B1 & B2 & B3 & B4 & $\mathrm{Al}$ & A2 & A3 & A4 & A5 & A6 & $\mathrm{U} 1$ & $\mathrm{U} 2$ \\
\hline O. longistaminat ${ }^{2}$ & $\begin{array}{c}28 \\
(0.007)\end{array}$ & $\begin{array}{c}11 \\
(0.05)\end{array}$ & $\begin{array}{c}23 \\
(0.005)\end{array}$ & 19 & & 4 & & & 18 & 12 & & \\
\hline O. sativa volunteers & 7 & 14 & 25 & 49 & 10 & 4 & 8 & 14 & 10 & 5 & & 6 \\
\hline O. sativa ratoons & 0.1 & & & & & & & & & & 0.2 & $\begin{array}{c}5 \\
(0.006)\end{array}$ \\
\hline O. sativa crop $^{3}$ & & & & & & 45 & & & & & $\begin{array}{c}52 \\
(4.7)\end{array}$ & \\
\hline
\end{tabular}

${ }^{1}$ Site names: B1: Anfani; B2: Gadza; B3: Goga; B4: Edozhigi; Al: Egunte; A2: Ekpelu; A3: Noyo; A4: Nsuba; A5: Ogidiga; A6: Obeagu; U1: Ekoi-Mbat; U2: Nung-Obong.

${ }^{2}$ Small amounts of $O$. longistaminata were present at site U2 but did not occur in transect quadrats.

${ }^{3}$ Site U1 was irrigated. At site A2 one farmer direct-seeded rice in February as an experiment.

Figures for average abundance are the estimated percentages of $25 \times 25 \mathrm{~cm}$ quadrats in which the plant was present, based on percentage occurrence in quadrats along transects through each habitat and the relative area of each habitat at each site. Zero values are omitted. 


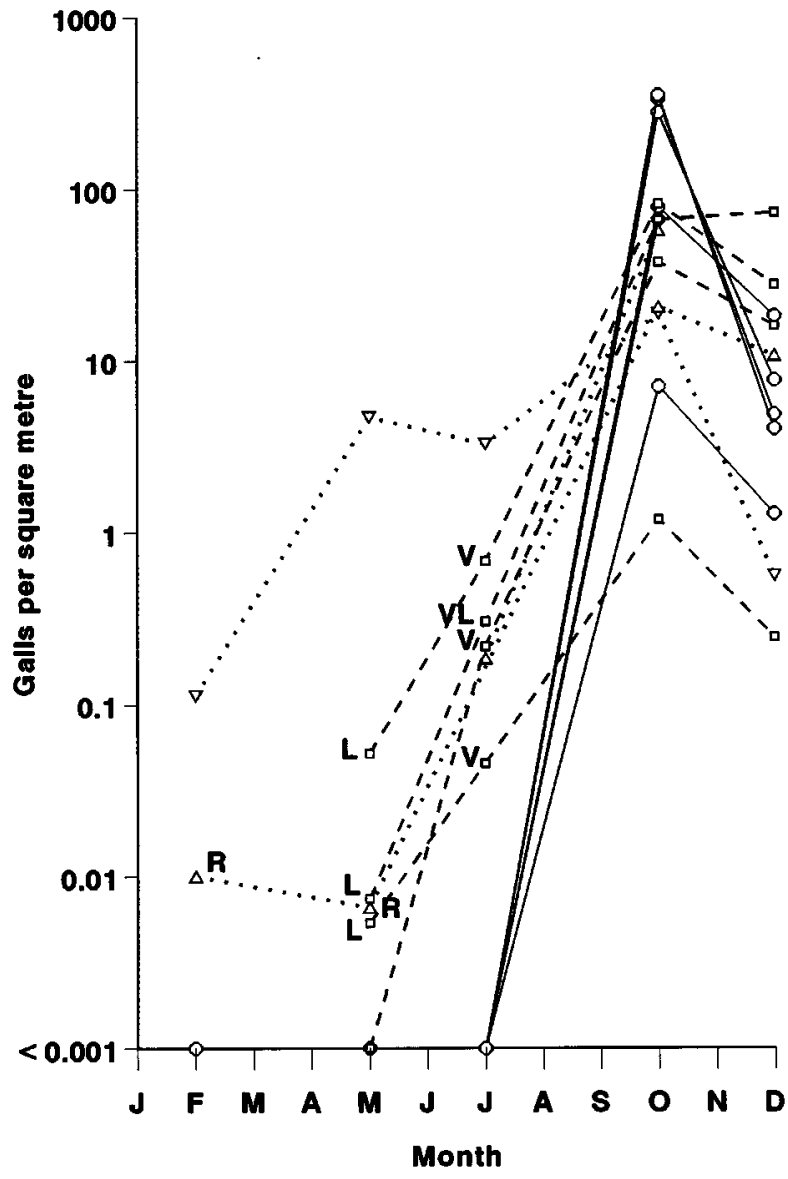

Fig. 1. Average numbers of Orseolia oryzivora galls per $\mathrm{m}^{2}$ through 1994 at rainfed sites near Bida $(\square--)$ and Abakaliki $(\bigcirc-)$, and irrigated $(\nabla---)$ and rainfed $(\triangle---)$ sites near Uyo. Letters by data points for February, May and July show where galls were found on ratoons (R) or volunteers (V) of Oryza sativa, or on $O$. longistaminata (L), rather than on rice crops. In December most galls were on ratoons at all the sites.

rice crops had not yet been planted at three of the Bida sites so the gall midge population was still dependent on noncrop hosts (i.e. wild rice and the volunteers and ratoons of $O$. sativa). But though $O$. longistaminata was still abundant, galls were only found on this species at one site in July, where they formed just $8 \%$ of the total. The remaining galls were on volunteers, which were now well grown. From July, gall densities increased rapidly and in October exceeded 35 per $\mathrm{m}^{2}$ on rice crops at three of the Bida sites (fig. 1). By December, the wet season was over, many rice fields had been harvested and most galls were on ratoons. At three sites, a few were also on $O$. longistaminata, representing $0.1 \%$ to $1.3 \%$ of the site totals.

The annual cycle at the rainfed site near Uyo, in the humid forest zone, was quite different. Fresh galls were found at low density on rice ratoons in February and May (table 6, fig. 1) showing that Orseolia oryzivora could survive the short dry season in this agroecological zone without a perennial wild host. At the irrigated site near Uyo, galls were present on rice crops year-round (fig. 1). Gall densities on the dry season rice crop at this site in February and May were much higher than at any of the rainfed sites but the subsequent increase during the wet season was much smaller, so the October peak was lower than at most rainfed sites (fig. 1).

Abakaliki, in the savannah/forest transition zone, showed even greater seasonal changes in gall densities than the other outbreak areas. No data were obtained on dry season hosts in this area because no galls could be found in February or May despite extensive sampling. Even in July, when the earliest-planted lowland rice crops were a month old, galls were only found at three of the six sites and average densities remained below 0.001 per $\mathrm{m}^{2}$. Five fields of upland rice near one site were sampled but had no galls. Searches of additional sites in the area only produced one patch of galls at moderate density (several per $\mathrm{m}^{2}$ ) on a lowland rice crop and a few galls on Oryza longistaminata and nursery beds. But from July the population increased very rapidly, reaching average gall densities from 78 to 349 per $\mathrm{m}^{2}$ by October at five sites, as high or higher than those in the other outbreak areas (fig. 1).

\section{Parasitism and predation in dissected galls}

The gregarious egg/larval endoparasitoid Platygaster diplosisae Risbec (Hymenoptera: Platygastridae) and the solitary larval/pupal ectoparasitoid Aprostocetus procerae (Risbec) (Hymenoptera: Eulophidae) were common in galls of Orseolia oryzivora. Aprostocetus procerae was previously known as Tetrastichus pachydiplosisae Risbec or A. pachydiplosisae (Risbec) (LaSalle \& Delvare, 1994). A few specimens of two parasitoids previously unrecorded from O. oryzivora were also found: a Eupelmus species (Hymenoptera: Eupelmidae) (one in a gall on volunteer rice near Bida in July) and a Neanastatus species near N. cinctiventris Girault (Hymenoptera: Eupelmidae) (four in galls on ratoons near Abakaliki in December).

At most sites near Bida and Uyo, percent parasitism by all parasitoids combined increased from July to December (fig. 2), following increases in gall densities but with a twomonth delay, reaching $30 \%$ to $50 \%$ by October and $50 \%$ to $70 \%$ by December. At Abakaliki, parasitism was much lower in October but increased very abruptly after that, reflecting the late but very rapid build-up of O. oryzivora there.

In October, when populations of O. oryzivora peaked, higher parasitism was loosely associated with lower gall midge infestation, but this may reflect differences between the outbreak areas rather than a direct causal link, because when sites in each area are considered separately no relationship is evident (fig. 3). Data for October also show differences in the relative abundance of the two main parasitoids in different areas: $A$. procerae was more abundant than $P$. diplosisae at the Bida sites while the reverse was true at Uyo (fig. 3). The two species also appear to differ in their preference for galls on Oryza sativa or O. longistaminata. In December, enough galls were found on both rice species at three sites to compare parasitism levels. At all three, parasitism by $A$. procerae was much lower on $O$. longistaminata than on O. sativa (mean values: $5 \%$ and $35 \%$ respectively) whereas for $P$. diplosisae it was higher (mean values: $36 \%$ and $25 \%$ respectively). Results from the only rainfed site where enough galls were found in May to assess parasitism suggest that both parasitoids survived the dry season in galls on O. longistaminata. At the irrigated site, both 


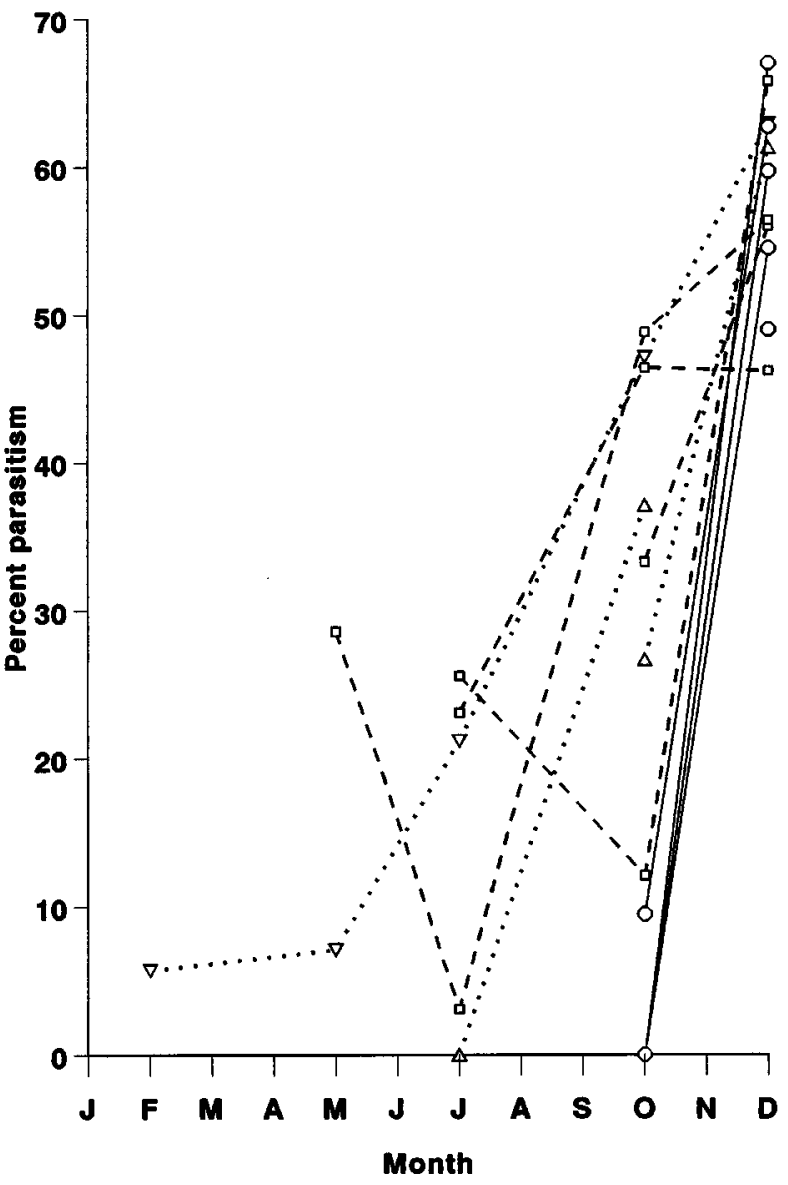

Fig. 2. Percent parasitism through 1994 in Orseolia oryzivora galls collected at rainfed sites near Bida $(\square--)$ and Abakaliki $\left(\mathrm{O}_{-}\right)$, and irrigated $\left(\nabla--_{--}\right)$and rainfed $\left(\triangle--_{--}\right)$sites near Uyo.

species persisted through the dry season at low levels in galls on $O$. sativa.

Predation of Orseolia oryzivora pupae in galls was low and did not increase with gall densities in the wet season. The average mortality in October was $1.5 \%(\mathrm{SE}=0.67 \%)$. Insects found in galls with predated O. oryzivora pupae were larvae of Diopsis spp. (Diptera: Diopsidae) or occasionally lepidopterous stemborers. As these are primarily phytophagous, the predation was probably largely 'accidental'. Pupal mortality from other causes (for example drowning in damaged galls or becoming trapped in distorted ones) was also low. The average in October was $3.6 \%(\mathrm{SE}=0.58 \%)$.

\section{Discussion}

Neither the no-choice host range tests nor extensive field sampling produced any evidence that $O$. oryzivora can develop on plants other than wild and cultivated rice (Oryza) species. This host range is narrower than that given by either Bonzi (1980) or Brenière (1983). However, the finding that the midge which infests Paspalum is not Orseolia oryzivora (Harris et al., 1999) explains the discrepancy

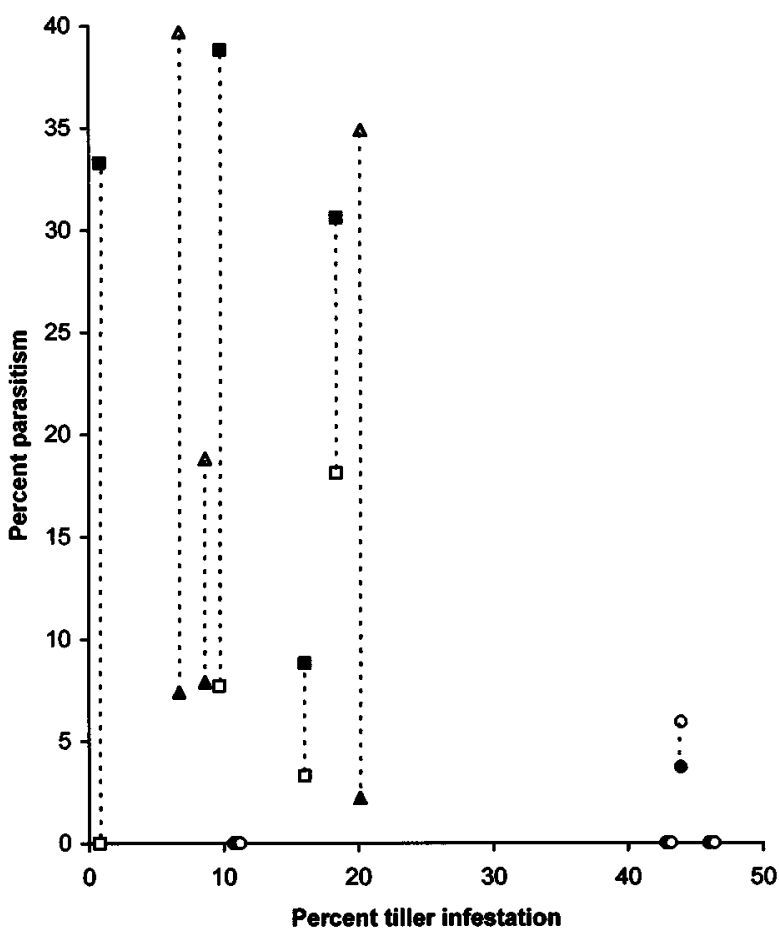

Fig. 3. Scatter plot of the percentage of Orseolia oryzivora galls parasitized by Aprostocetus procerae (solid symbols) and Platygaster diplosisae (hollow symbols) in October 1994 against the percentage of tillers with galls, for sites near Bida $(\square)$, Abakaliki $(\bigcirc)$ and Uyo $(\triangle)$. Data points joined by broken lines refer to the same site.

between Bonzi's conclusions and our own, because he only recorded galls on Oryza species, P. scrobiculatum and Paspalum polystachyum, and the latter taxon is now considered to be a form of P. scrobiculatum (Johnson, 1997).

Brenière (1983), quoting Descamps and Hidaka, gives a wider host range including Ischaemum sp. and Echinochloa colona (Linn.) Link (Poaceae). Descamps (1956) does not mention either of these, so they are presumably listed by Hidaka. Unfortunately, Brenière gives no details of Hidaka's paper apart from the year of publication but it almost certainly relates to his research on the Asian rice gall midge (Hidaka, 1974). It therefore seems that these host records have been mistakenly transferred from Orseolia oryzae to $O$. oryzivora. In fact they are almost certainly incorrect for $O$. oryzae also, because more recent studies have shown that what was assumed to be one Asian Orseolia species with a wide host range is actually a group of at least eight similar species, each restricted to one or two genera of grasses (Gagné, 1985; Natarajan et al., 1988).

Although we can find no African records of onion leaf galls on Ischaemum there are a few for Echinochloa. A single gall was found on an Echinochloa species in Tanzania (E.A. Akinsola, M. Ukwungwu \& E. Umeh, 1994, unpublished report on a trip to Kapunga irrigated rice project, Tanzania, 9-18 April 1994) and Descamps (1956) mentions an 


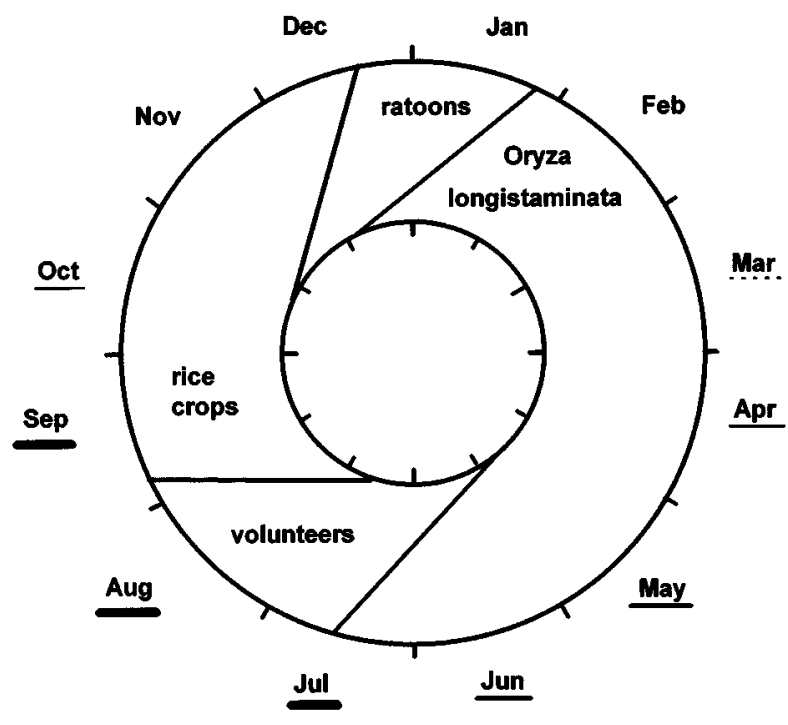

Fig. 4. Annual cycle of Orseolia oryzivora in the moist savannah agroecological zone, based on sampling at sites near Bida, Nigeria, in 1994. Average rainfall in each month is roughly indicated by the thickness of underlining.

undetermined gall midge living on Echinochloa stagnina (Retz.) P. Beauv. which he regarded as a separate species. Given the negative results from E. colona and E. stagnina in the present study, the Orseolia species infesting this genus in Africa is probably not $O$. oryzivora. However, this cannot be determined conclusively until gall midge specimens from African Echinochloa are available for taxonomic study.

Field sampling showed that the importance of different hosts to the dry season survival of $O$. oryzivora varied according to the length of the dry season (which to a large extent defines agroecological zones) and the rice cropping pattern. In the humid forest zone (Uyo area) the pest was able to persist through the short dry season on rice ratoons at the rainfed site and on dry season rice crops at the irrigated site. But at rainfed sites in the moist savannah zone (Bida area), O. oryzivora survived the longer dry season on wild $O$. longistaminata, while volunteers and ratoons provided 'bridges' between the wild host and wet season rice crops (fig. 4). In the savannah/forest transition zone (Abakaliki area) the annual cycle was unclear because no galls were found before July but, given the length of the dry season and the absence of live ratoons early in the year, it probably resembles that in the savannah. In northern Cameroon, which has an even longer dry season than Bida, Descamps (1956) found Orseolia oryzivora larvae surviving the dry season on the dormant buds of wild rice. He refers to this rice as Oryza barthii but the annual O. barthii and the perennial $O$. longistaminata had not been taxonomically separated at that time. As the plants he describes persisted from one wet season to the next, they were almost certainly the latter species.

The new information on host range and the roles of different hosts improves prospects for reducing $O$. oryzivora by controlling its non-crop hosts (wild rices, ratoons and volunteers). This is feasible at single-cropped sites provided that wild rice is not too abundant and that uncultivated habitats hold only a small proportion of the gall midge population, as was the case at our study sites. Measures to reduce non-crop hosts at such sites are probably most effective at the start of the wet season, after the previous year's ratoons have died off and before new rice crops are planted, so that volunteers and wild rice are the only hosts present. One way to reduce volunteers without using labour at this time (which is often one of labour-shortage) is to modify harvesting and threshing practices to reduce the amount of grain spilled on the fields.

Comparing the three outbreak areas, there was no direct relationship between the densities of galls in May and peak densities on rice crops in October: Abakaliki had the lowest gall densities in May but the highest peak densities. Thus the initial size of the population seems much less important in determining the peak infestation level than the rate of increase during the wet season. Abakaliki may have shown the most rapid increases because this area has a dry season severe enough to greatly reduce natural enemies of $O$. oryzivora and a wet season intense and prolonged enough to allow the pest to multiply very rapidly. A carry-over of natural enemies from dry to wet season rice crops could explain the low increase rate at the irrigated site near Uyo.

In northern Cameroon in the 1950s, gall midge population increase on wild rice in large areas of uncultivated marshland around the rice fields appeared to be very important in producing outbreaks (Descamps, 1956). But at our Nigerian field sites population increase took place predominantly on Oryza sativa, rather than on wild hosts, and very largely on rice crops themselves. This was even the case at Bida, where wild O. longistaminata is important for dry season survival. Therefore measures which reduce the rate of increase on rice crops or shorten the period they are available during the wet season are probably essential for major improvements in the management of Orseolia oryzivora in Nigeria. Controlling non-crop hosts is unlikely to be sufficient on its own.

Early, synchronized planting is an important control measure which reduces the period that rice crops are available to the midge, but its implementation is often constrained by uncertain water availability and shortages of labour and fertilizer early in the wet season. Therefore future research on the management of O. oryzivora is probably best focused on slowing the pest's rate of increase on the crop, through improvements to biological control and varietal resistance. With respect to biological control, our results and those of earlier studies (Descamps, 1956; Dakouo et al., 1988; Umeh \& Joshi, 1993) suggest that $P$. diplosisae and A. procerae are the only indigenous parasitoids with potential as natural biological control agents of O. oryzivora. Though their impact appears to be limited by delays in their responses to increasing host density, the discovery that at least one of these parasitoids also attacks the Orseolia species infesting Paspalum has suggested new ways of enhancing their effectiveness (Harris et al., 1999).

\section{Acknowledgements}

This work was funded by the UK Department for International Development under Holdback Project R5619(H). We thank Mr A. Kehinde, project technician at Ibadan, Drs J. LaSalle and A. Polaszek of CABI Bioscience, and Dr I.O. Akobundu, Mr Agyakwa, Dr N.Q. Ng and Dr S. 
Jagtap, all of IITA, for providing assistance in various ways and we gratefully acknowledge all the national staff who collaborated, in particular Mr O. Adumike and $\mathrm{MrO}$. Oreke (formerly Abakaliki Zone, Enugu State Agricultural Development Project), Mr A. Razaq and Mr M. Bashiru (National Cereals Research Institute (NCRI) Badeggi), Chief Ibok and Mr C.D. Umoh (NCRI, Uyo) and the late Dr D. Meyen (Akwa-Ibom State Agricultural Development Project).

\section{References}

Alam, M.S., Kaung Zan \& Alluri, K. (1985) Gall midge (GM) Orseolia oryzivora $\mathrm{H}$ \& $\mathrm{G}$ in Zambia. International Rice Research Newsletter, 10(2), 15-16.

Anon. (1987) Orseolia oryzivora. Fiche Technique de CIRAD-IRAT, Division de Défense des Cultures. Montpellier, France, CIRAD-IRAT.

Bonzi, S.M. (1980) Wild host plants of the rice gall midge Orseolia oryzae W.M. (Diptera: Cecidomyiidae) in UpperVolta. West Africa Rice Development Association Technical Newsletter 2, 5-6.

Bouchard, D., Ouedraogo, A., Boivin, G. \& Amadou, K. (1992) Mass rearing and life-cycle of the African rice gall midge, Orseolia oryzivora H. \& G., in Burkina Faso. Tropical Pest Management 38, 450-452.

Brenière, J. (1983) The principal insect pests of rice in West Africa and their control. $87 \mathrm{pp}$. Monrovia, Liberia, West Africa Development Association.

Commonwealth Institute of Entomology (1984) Distribution maps of insect pests, series A, map no. 464: Orseolia oryzivora. Wallingford, CAB International.

Dakouo, D., Nacro, S. \& Sie, M. (1988) Evolution saisonniere des infestations de la cecidomyie du riz, Orseolia oryzivora H. et G. (Diptera, Cecidomyiidae) dans le sud-ouest du Burkina Faso. Insect Science and its Application 9, 469-473.

Descamps, M. (1956) Deux diptères nuisibles au riz dans le Nord Cameroun, Pachydiplosis oryzae Wood Mason et Pachylophus sp. aff lugens Loew. Phytiatrie-Phytopharmacie 5, 109-116.

Gagné, R.J. (1985) A taxonomic revision of the Asian rice gall midge, Orseolia oryzae (Wood-Mason), and its relatives (Diptera: Cecidomyiidae). Entomography 3, 127-162.

Harris, K.M \& Gagné, R.J. (1982) Description of the African rice gall midge, Orseolia oryzivora sp. n., with comparative notes on the Asian rice gall midge O. oryzae (Wood-Mason) (Diptera: Cecidomyiidae). Bulletin of Entomological Research 72, 467-472.
Harris, K.M., Williams, C.T., Okhidievbie, O., LaSalle, J. \& Polaszek, A. (1999) Description of a new species of Orseolia (Diptera: Cecidomyiidae) from Paspalum in West Africa, with notes on its parasitoids, ecology and relevance to natural biological control of the African rice gall midge, $O$. oryzivora Harris \& Gagné. Bulletin of Entomological Research 89, 000-000.

Hidaka, T. (1974) Recent studies on the rice gall midge, Orseolia oryzae (Wood-Mason), Cecidomyiidae: Diptera. Review of Plant Protection Research 7, 99-143.

Johnson, D.E. (1997) Weeds of rice in West Africa. Bouaké, Côte d'lvoire, West Africa Rice Development Association.

LaSalle, J. \& Delvare, G. (1994) Aprostocetus procerae (Risbec): a senior synonym of Tetrastichus pachydiplosisae Risbec (Hymenoptera: Eulophidae). African Entomology 2, 133-135.

Natarajan, K., Mathur, K.C. \& Rajamani, S. (1988) Host range of Asian rice gall midge (Orseolia oryzae) (Diptera: Cecidomyiidae). Indian Journal of Agricultural Sciences 59, 110-113.

Taylor, D.R., Fomba, S.N., Fannah, S.J. \& Bernard, H.M. (1995) African rice gall midge in Sierra Leone. International Rice Research Newsletter 20(1), 27.

Ukwungwu, M.N. \& Joshi, R.C. (1992) Distribution of the African rice gall midge, Orseolia oryzivora Harris and Gagné and its parasitoids in Nigeria. Tropical Pest Management 38, 241-244.

Ukwungwu, M.N., Winslow, M.D. \& John, V.T. (1989) Severe outbreak of rice gall midge (GM) in the savanna zone, Nigeria. International Rice Research Newsletter 14(4), 36-37.

Umeh, E.D.N. \& Joshi, R.C. (1993) Aspects of the biology, ecology and natural biological control of the African rice gall midge, Orseolia oryzivora Harris and Gagné (Dipt., Cecidomyiidae) in south east Nigeria. Journal of Applied Entomology 116, 391-398.

Williams, C.T., Ukwungwu, M.N., Singh, B.N., Okhidievbie, O. \& Nnabo, J. (1999) Farmer-managed trials in southeast Nigeria to evaluate the rice variety Cisadane and estimate yield losses caused by the African rice gall midge, Orseolia oryzivora Harris \& Gagné. International Journal of Pest Management 45, 117-124.

(Accepted 17 October 1999) (c) CAB International, 1999 


$$
\text { Your ibrar } 1, \text { i eo is ler ot } k
$$

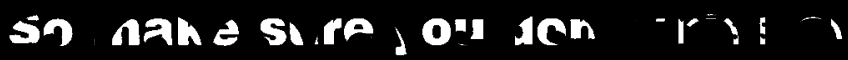

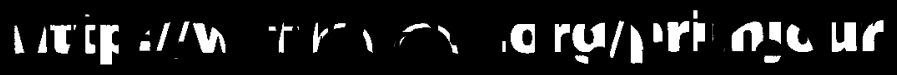

or $m \cap r . \quad \therefore \quad \therefore n$ if virtor

\section{The Internet version will be exactly the same} as the print and will includer

- Contents page

- Full text of original research papers and review articles

- Short communications

- Critiques section

- Review articles

- Book reviews

- Aims \& scope

- Submission instructions for authors

- Supplements and special issues (when published)

- Links from cited references to bibliographic databases

$$
\text { special offer for } \mathbf{2 0 0 0}
$$

Organizations with print subscriptions get FREE site-wide aconese to the Internaturacion of this title 